\title{
Helodermatid lizard from the Mio-Pliocene oak-hickory forest of Tennessee, eastern USA, and a review of monstersaurian osteoderms
}

Jim I. Mead, Blaine W. Schubert, Steven C. Wallace, and Sandra L. Swift

Acta Palaeontologica Polonica 57 (1), 2012: 111-121 doi: http://dx.doi.org/10.4202/app.2010.0083

The extant venomous Gila monster and beaded lizards, species of Heloderma, live today in southwestern USA and south along the Pacific coastal region into Central America, but their fossil history is poorly understood. Here we report helodermatid osteoderms (dermal ossicles) from the late Miocene-early Pliocene Gray Fossil Site, eastern Tennessee USA. Twenty-three species of mammals are known from the fauna including abundant Tapirus polkensis, as well as fishes, anurans, salamanders, turtles, Alligator, birds, and snakes. Beaded lizards belong to the Monstersauria, a clade that includes Primaderma + Paraderma + Gobiderma + Helodermatidae (Estesia, Eurheloderma, Lowesaurus, and Heloderma).

Osteoderms of lizards in this clade are unique within Squamata; they typically are circular to polygonal in outline, domed to flat-domed in cross-section, have a vermiculate surface texture, are not compound structures, and do not have imbricate surfaces as on many scincomorph and anguid lizards. We review and characterize the osteoderms of all members of Monstersauria. Osteoderms from the cranium, body, and limbs of Heloderma characteristically have a ring-extension (bony flange) at least partly surrounding the dome. Its presence appears to be a key character distinct to all species of Heloderma, consequently, we propose the presence of a ring-extension to be an apomorphy. Three osteoderms from the Gray Fossil Site range from 1.5 to $3.0 \mathrm{~mm}$ in diameter, have the circular shape of helodermatid osteoderms with a domed apical surface, and have the ring-extensions, permiting generic identification. Macrobotanical remains from the Gray Fossil Site indicate an oak-hickory subtropical forest dominated by Quercus (oak) and Carya (hickory) with some conifer species, an understorey including the climbing vines Sinomenium, Sargentodoxa, and Vitis. Plant and mammal remains indicate a strong Asian influence.

Key words: Reptilia, Squamata, Helodermatidae, Heloderma, beaded lizards, Hemphillian, Miocene, Pliocene, Tennessee, North America.

Jim I. Mead [mead@etsu.edu], Blaine W. Schubert [schubert@etsu.edu], Steven C. Wallace [wallaces@etsu.edu], and Sandra L. Swift [Sandra.swiftone@yahoo.com], Department of Geosciences, and the Don Sundquist Center of Excellence in Paleontology, East Tennessee State 
University, Johnson City, TN 37614 USA.

This is an open-access article distributed under the terms of the Creative Commons Attribution License (for details please see creativecommons.org), which permits unrestricted use, distribution, and reproduction in any medium, provided the original author and source are credited.

Fofill Full text $(596.5 \mathrm{kB})$ 